Jurnal DIALOGIKA Manajemen dan Administrasi

Homepage: https://ejournal.unma.ac.id/index.php/dialogika

Vol. 1, No. 2 April 2020, halaman: $53 \sim 61$

E-ISSN: 2720-9865, P-ISSN: 2716-3563

DOI : https://doi.org/10.31949/dialogika.v1i2.2169

\title{
PENGARUH KEPEMIMPINAN KEPALA SEKOLAH DAN BUDAYA SEKOLAH TERHADAP KINERJA GURU BERDAMPAK PADA HASIL BELAJAR SISWA
}

\author{
Ade Prayoga \\ Mahasiswa Pascasarjana, Universitas Majalengka, Jawa Barat, Indonesia \\ e-mail korespondensi: adeprayoga@gmail.com
}

Disubmit Februari 2020 , Diterima Maret 2020 , Diterbitkan April 2020

Submitted February 2020, Accepted March 2020, Published April 2020

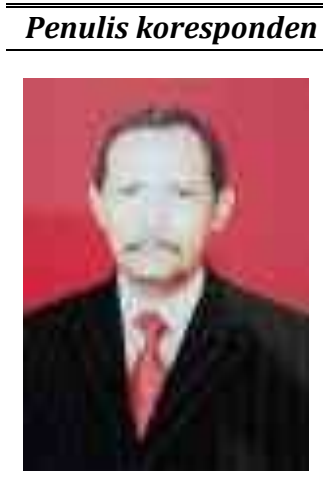

\begin{abstract}
The progress of a nation is very dependent on human resources (HR). Education plays a very important role in the process of improving human resources and education is a major factor in the formation of a qualified human person to face competition entering the era of globalization which is very competitive both in the field of education and technology, so the need for change and development in the world of education. This study aims to find out analyzing descriptively and verification of aspects of leadership, school culture and teacher performance. This research method is a quantitative research method with descriptive and verification analysis techniques. Descriptive method using the calculation of frequency distribution, scoring and average value, while the verification method using path analysis. The sampling technique was taken by cluster proportional random sampling. Descriptive research results indicate that the principal's leadership, school culture, teacher performance and quality of student learning outcomes are in the good category. The results of the verification study prove that leadership and culture have a very positive and significant influence on teacher performance either partially or simultaneously. Teacher performance has a positive and significant effect on the quality of student learning outcomes.
\end{abstract}

Keywords: Headmaster Leadership, School Culture, Teacher Performance And Quality Of

Jurnal DIALOGIKA

Manajemen dan

Administrasi

diterbitkan oleh

Program Study

Administrasi Publik

Pascasarjana

Universitas Majalengka \begin{abstract}
Student Learning Outcomes.
Abstrak

Kemajuan suatu bangsa amat bergantung pada sumber daya manusia (SDM). Pendidikan memegang peranan yang sangat penting dalam proses peningkatan SDM dan pendidikan merupakan faktor utama dalam pembentukkan pribadi manusia yang berkualitas untuk menghadapi persaingan memasuki era globalisasi yang sangat kompetitif baik dalam bidang pendidikan maupun teknologi, sehingga perlu adanya perubahan dan pengembangan dalam dunia pendidikan. Penelitian ini bertujuan untuk mengetahui menganalisis secara deskriptif dan verifikatif dari aspek kepemimpinan, budaya sekolah dan kinerja guru. Metode penelitian ini adalah metode penelitian kuantitatif dengan teknik analisis secara deskriptif dan verifikatif. Metode deskriptif dengan menggunakan perhitungan distribusi frekuensi, skoring dan nilai rata-rata, sedangakn metode verifikatif dengan menggunakan analisis jalur. Teknik sampling diambil secara cluster proporsional random sampling. Hasil penelitian deskriptif menunjukkan bahwa kepemimpinan kepala sekolah, budaya sekolah, kinerja guru dan kualitas hasil belajar siswa berada pada kategori baik. Hasil penelitian secara verifikatif membuktikan bahwa kepemimpinan dan budaya sangat berpengaruh positif dan signifikan terhadap kinerja guru baik secara parsial maupun simultan. Kinerja guru berpengaruh positif dan signifikan terhadap kualitas hasil belajar siswa.
\end{abstract}

Kata Kunci : Kepemimpinan Kepala Sekolah, Budaya Sekolah, Kinerja Guru Dan Kualitas Hasil Belajar Siswa. 


\section{PENDAHULUAN}

Pemerintah memberikan perhatian serius terhadap upaya peningkatan kemampuan profesional guru melalui kebijakan sertifikasi guru (Permendiknas No. 18 Tahun 2007). Namun menurut Unifah Rosyidi (Kompas, 7 Oktober 2009: 12), kinerja guru yang sudah lulus proses sertifikasi masih belum memuaskan. Dari hasil survey yang dilakukan Persatuan Guru Republik Indonesia (PGRI) hasil sementara yang diperoleh di 16 provinsi dari total 28 provinsi yang sedang disurvey, ditemukan bahwa dampak program sertifikasi kurang memuaskan. Para guru yang telah lulus sertifikasi diharapkan mengalami perubahan pola kerja. motivasi kerja, pembelajaran, dan peningkatan kualitas diri. Namun ternyata masih tetap sama seperti sebelumnya, kinerja guru tetap rendah. Kondisi kinerja guru yang belum memuaskan saat ini merupakan tantangan bagi semua pihak untuk selalu berusaha mencari jalan bagi upaya peningkatan kinerja guru menuju terciptanya guru-guru profesional.

Kinerja guru banyak disangkutpautkan dengan rendahnya hasil belajar dan mutu pendidikan. Guru sebagai makhluk sosial juga memerlukan kebutuhan yang lain untuk dapat bekerja dengan baik. Untuk dapat berpikir serta bekerja secara maksimal dalam kerjanya, guru sangat dipengaruhi oleh lingkungan kerja dimana mereka berada serta kepala sekolah yang profesional. Mungkin dengan guru berada dalam lingkungan kerja yang baik dimana di dalamnya terdapat suatu kondisi yang memacu bekerja dengan baik, mempunyai rasa tanggung jawab yang tinggi, serta gotong royong yang baik, maka akan dapat menciptakan suatu kondisi kerja yang baik sehingga akan dapat lebih meningkatkan kinerja seorang guru untuk bekerja. Selain itu, guru juga akan dapat melaksanakan kegiatan PBM, membangkitkan potensi siswa dalam melaksanakan tugas-tugasnya dengan penuh tanggung jawab apabila didukung oleh kondisi tubuh, suasana kejiwaan, sarana prasarana serta proses pengelolaan organisasi sekolah yang ada mendukung bagi timbulnya semangat kerja yang tinggi.

Perlu diketahui bahwa tidak semua masyarakat dimana para guru berada adalah masyarakat yang seperti telah disebutkan di atas. Hal tersebut berakibat pada tindakan guru yang berbeda-beda dalam melaksanakan tugasnya. Beratnya tugas yang menjadi tanggung jawab guru apabila tidak dilaksanakan dalam suatu sistem kerja yang rapi menjadikan banyak guru yang kehilangan semangat kerja di dalam melaksanakan tugasnya. Hilangnya semangat kerja ini merupakan masalah pokok dan mendasar yang harus dihindari. Oleh sebab itu, tugas yang berat dari seorang guru ini pada dasarnya hanya dapat dilaksanakan oleh guru yang memiliki kinerja yang tinggi. Selain itu guru mempunyai tugas untuk mendidik, mengajar dan melatih. Mendidik berarti meneruskan dan mengembangkan nilainilai hidup, mengajar berarti meneruskan dan mengembangkan ilmu pengetahuan, melatih berarti mengembangkan keterampilan-keterampilan pada siswa. Dalam melaksanakan tugas dan tanggung jawab tersebut, seorang guru dituntut memiliki beberapa kemampuan dan keterampilan tertentu.

Dalam rangka menciptakan guru profesional yang berkinerja tinggi pada setiap lembaga pendidikan,Undang-Undang Republik Indonesia Nomor 14 Tahun 2005 Pasal 8 tentang menjadi pendidik profesional tersebut ditegaskan, "Guru wajib memiliki kualifikasi akademik, kompetensi, sertifikasi pendidik, sehat jasmani dan rohani, serta memiliki kemampuan untuk mewujudkan tujuan pendidikan nasional". Dalam hal ini guru yang melaksanakan pekerjaan pada lembaga pendidikan wajib memiliki kualifikasi tersebut yang menjamin keahlian, kemahiran atau kecakapannya sebagai pendidik profesional.

Kriteria-kriteria wajib tersebut merupakan standar mutu yang harus dipenuhi oleh guru. Profesionalitas guru yang memenuhi standar tersebut merupakan pendukung terciptanya kualitas 
seorang guru dalam menjalankan pekerjaannya. Terciptanya kualitas kinerja guru yang profesional di sekolah membutuhkan dukungan peran kepala sekolah yang kompeten sebagai leader dan manager (Wahyudi, 2009: 29-36). Di satu sisi, kepala sekolah berperan sebagai pemimpin (leader) yang memiliki visi ke masa depan yang jelas dan dapat diwujudkan serta mampu mendorong proses transparansi di sekolah. Di sisi lain, kepala sekolah berperan sebagai manajer, yang memiliki strategi-strategi yang efektif dan efisien untuk mengimplementasikan berbagai kebijakan dan keputusan yang telah ditetapkan.

Selain faktor kepemimpinan, budaya organisasi juga akan mempengaruhi setiap perilaku. Hal itu tidak hanya membawa dampak pada keuntungan organisasi sekolah secara umum, namun juga akan berdampak pada perkembangan kemampuan dan efektivitas kerja guru itu sendiri. Budaya juga dapat mempengaruhi sikap dan perilaku anggota organisasi termasuk sikap guru yang memiliki efek positif yang konsisten terhadap prestasi siswa. Menurut Pidarta (2000:162) Selain itu budaya juga sangat berpengaruh dalam pembentukan sekolah yang efektif. Sekolah sebagai suatu bentuk organisasi punya budaya tersendiri yang membentuk corak dari sistem yang utuh dan khas. Kekhasan budaya sekolah tidak lepas dari visi dan proses pendidikan yang berlangsung yang menuntut keberadaan unsur- unsur atau komponen-komponen sekolah sebagai bidang garapan organisasi. Unsur-unsur tersebut saling berinteraksi dan memiliki keterkaitan antara satu dengan yang lain, dan adakalanya suatu budaya bisa dipakai terus, juga adakalanya harus diperbaiki dan juga adakalanya harus dibuang untuk diganti dengan budaya baru.

Budaya sekolah dipandang sebagai eksistensi suatu sekolah yang terbentuk dari hasil saling mempengaruhi antara tiga faktor, yaitu sikap dan kepercayan orang yang berada di lingkungan sekolah dan di luar lingkungan sekolah, norma budaya sekolah dan hubungan antar individu yang ada di sekolah. Budaya sekolah yang efektif menggambarkan ketiga faktor tersebut berjalan sinergi, sehingga diperoleh program yang rasional dan diimplementasikan berdasarkan nilai kemanusiaan, profesionalisme, dan pemberdayaan. Pada sekolah yang berkualitas, para personel merasakan adanya kepuasan bergaul dan berhubungan satu sama lain dan mereka enggan untuk meninggalkan sekolahnya, bukan hanya disebabkan gaji yang memadai, tetapi lebih pada adanya penghargaan yang profesional.

\section{TINJAUAN PUSTAKA}

Kepemimpinan sebagai ujung tombak bagi perkembangan dan stabilitas sekolah yang secara otomatis dapat menciptakan budaya sekolah yang baik dan meningkatkan kinerja semua onggota organisasi. Kepemimpinan mempunyai peran sebagai leader, innovator, supervisor, motivator, dan sebagai seorang manajer mampu menciptakan suasana kerja, lingkungan belajar, dan pencapaian kualitas sekolah menjadi sebuah sekolah yang efektif dan menciptakan lulusan yang mempunyai peranan yang baik di dalam masyarakat. Kepemimpinan kepala sekolah yang kuat sangat berdampak terhadap kemajuan dan dapat menunjang keberhasilan sekolah. Kepala sekolah dalam hal ini perlu mensinergikan komponen-komponen sekolah seperti guru, murid, dan karyawan sekolah lainnya agar tercipta budaya sekolah yang kondusif yang diciptakan di sekolah sehingga budaya sekolah yang kuat akan mempengaruhi setiap perilaku. Budaya juga dapat mempengaruhi sikap dan perilaku anggota organisasi termasuk sikap dan kinerja guru yang memiliki efek posisitf yang konsisten terhadap prestasi yang kemudian akan tercipta sekolah yang baik.

Pengaruh antarvariabel penelitian menggunakan model mediating yang merupakan bagian dari analisis jalur (path analysis) Kerlinger (2006:900) menjelaskan bahwa analisis jalur adalah bentuk terapan dari analisis multiregresi. Penelitian ini digunakan diagram jalur untuk membantu masalah atau menguji hipotesis yang kompleks. Model mediating atau perantara dimana variabel $Y$ memodifikasi pengaruh variabel $\mathrm{X}$ terhadap variabel $\mathrm{Z}$ dan $\mathrm{Y}$ 
merupakan variabel intervening. Menurut Tuckman dalam Sugiyono, (2007) variabel intervening adalah variabel yang secara teoritis mempengaruhi hubungan antara variabel independen dengan variabel dependen menjadi hubungan yang tidak langsung dan tidak dapat diamati dan diukur. Variabel ini merupakan variabel penyela/antara variabel independen dengan variabel dependen, sehingga variabel independen tidak langsung mempengaruhi berubahnya atau timbulnya variabel dependen. Model ini dapat digambarkan sebagai berikut.

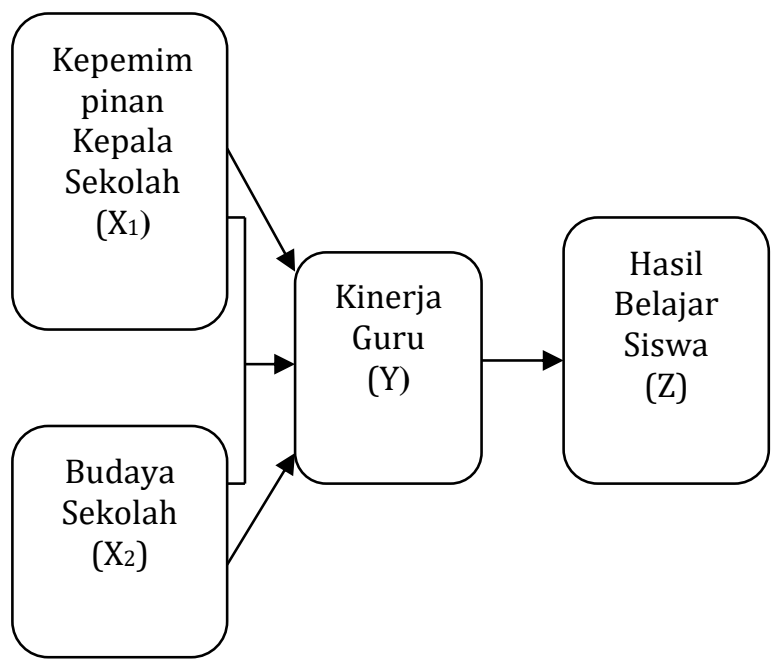

Gambar 1 Model Penelitian

Berdasarkan deskripsi teoritis dan kerangka pikir, hipotesis dalam penelitian ini dapat dirumuskan sebagai berikut.

1. Terdapat pengaruh yang signifikan kepemimpinan kepala sekolah terhadap kinerja guru di SMA Negeri di Kabupaten Majalengka,

2. Terdapat pengaruh yang signifikan budaya sekolah terhadap kinerja guru di SMA Negeri di Kabupaten Majalengka,

3. Terdapat hubungan yang signifikan kepemimpinan kepala sekolah dan budaya organisasi sekolah terhadap kinerja guru di SMA Negeri di Kabupaten Majalengka,

4. Terdapat pengaruh yang signifikan antara kinerja guru terhadap hasil belajar siswa di SMA Negeri di Kabupaten Majalengka.

\section{METODE PENELITIAN}

Pendekatan pada penelitian ini adalah penelitian kuantitatif, yaitu menurut Musfiqon, (2012:59) penelitian yang difokuskan pada kajian fenomena objektif untuk dikaji secara kuantitatif. Penelitian pengumpulan data dilakukan secara kuantitatif. Penelitian ini termasuk jenis penelitian expost facto, menurut Sugiyono, (2007 : 7) yaitu penelitian yang bertujuan untuk menyelidiki peristiwa yang telah terjadi dan kemudian merunut ke belakang untuk mengetahui faktor-faktor yang menyebabkan terjadinya peristiwa tersebut. Penelitian ini menggunakan metode deskriptif korelasional, yaitu penelitian yang berusaha menghubungkan dua variabel atau lebih berdasarkan fakta-fakta yang telah terjadi melalui pengumpulan data, pengolahan data, kemudian menganalisis, dan terakhir menjelaskan.

Populasi pada penelitian ini adalah sejumlah guru SMA Negeri di Kabupaten Majalengka yang terdiri dari 16 sekolah Negeri, kemudian dengan menggunakan Cluster Sampling didapat 4 sekolah yang menjadi populasi dalam penelitian ini. Populasi dalam penelitian ini sejumlah 320 guru. Penentuan sampel untuk guru menggunakan cluster sampling (area sampling). Pengambilan sampel dari populasi penelitian dilakukan dengan teknik Proporsional Random Sampling, menurut Sugiyono, (2010:120) Proporsional Random Sampling yaitu cara pengambilan sampel dari anggota populasi dengan menggunakan cara acak tanpa memperhatikan strata dalam populasi tersebut. Teknik analisis data yang digunakan adalah analisis jalur (Path Analysis).

Menurut Sugiyono ( 2014:297 ), analisis jalur adalah analisis untuk melukiskan dan menguji model hubungan antar variabel yang berbentuk sebab akibat (bukan bentuk hubungan interaktif/ reciprocal). Dengan demikian, dalam model hubungan antar variabel tersebut, terdapat variabel independen yang dalam hal ini disebut variabel eksogen (Exogeneus), dan variabel dependen yang disebut variabel endogen (Endogenous). 
Melalui analisis jalur ini akan dapat ditemukan jalur mana yang paling tepat dan singkat suatu variabel independen menuju variabel dependen terakhir.

\section{HASIL PENELITIAN DAN PEMBAHASAN}

Berdasarkan hasil pengolahan data maka hasil penelitian diuraikan sebagai berikut :

Tabel 1 Rekapitulasi Tanggapan Responden Mengenai Kepemimpinan Kepala Sekolah

\begin{tabular}{ccrcccc}
\hline No & Dimensi & $\begin{array}{c}\text { Skor } \\
\text { actual }\end{array}$ & $\begin{array}{c}\text { Skor } \\
\text { ideal }\end{array}$ & \% & $\begin{array}{c}\text { Mean } \\
\text { skor }\end{array}$ & $\begin{array}{c}\text { Kate- } \\
\text { gori }\end{array}$ \\
\hline 1 & $\begin{array}{l}\text { Keahlian } \\
\text { Konseptual }\end{array}$ & 3650 & 4410 & 82.77 & 4.14 & Baik \\
2 & $\begin{array}{l}\text { Keahlian } \\
\text { Sosial }\end{array}$ & 3464 & 4410 & 78.55 & 3.93 & Baik \\
3 & $\begin{array}{l}\text { Keahlian } \\
\text { Teknik }\end{array}$ & 3070 & 3675 & 83.54 & 4.18 & Baik \\
\cline { 2 - 6 } & Total & 10184 & 12495 & 81.62 & 4.08 & Baik \\
\hline
\end{tabular}

Sumber : Pengolahan Data

Berdasarkan Tabel $4.8 \mathrm{di}$ atas, diperoleh informasi bahwa total skor aktual yang diperoleh dari seluruh pernyataanpernyataan yang membentuk variabel kepamimpinan kepala sekolah adalah sebesar 10184 dan skor ideal sebesar 12495, sedangkan nilai total persentase yang diperoleh adalah sebesar $81,62 \%$ dan nilai mean skor sebesar 4,08 termasuk dalam kategori baik. Hal ini menunjukan bahwa kepemimpinan kepala sekolah baik. Kategori sangat baik pada kepemimpinan kepala sekolah jika digambarkan dengan menggunakan garis kontinum maka akan tampak sebagai berikut:

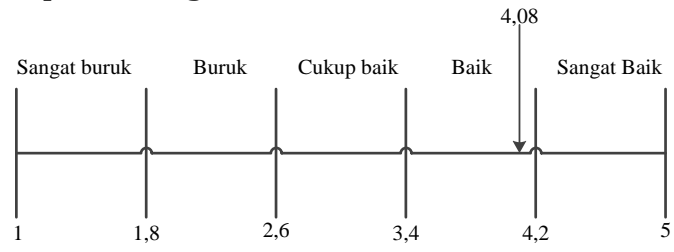

Gambar 1 Garis Kontinum Kategorisasi

Penilaian Variabel Kepemimpinan Kepala Sekolah

Untuk variabel Budaya Sekolah, diperoleh hasil sebagai berikut.

Tabel 2 Rekapitulasi Tanggapan Responden Mengenai Budaya Sekolah

\begin{tabular}{|c|c|c|c|c|c|c|}
\hline No & Dimensi & $\begin{array}{c}\text { Skor } \\
\text { actual }\end{array}$ & $\begin{array}{l}\text { Skor } \\
\text { ideal }\end{array}$ & $\%$ & $\begin{array}{c}\text { Mean } \\
\text { skor }\end{array}$ & $\begin{array}{c}\text { Kate- } \\
\text { gori }\end{array}$ \\
\hline 1 & $\begin{array}{l}\text { Individual } \\
\text { Autonomy }\end{array}$ & 1255 & 1470 & 85.38 & 4.27 & $\begin{array}{c}\text { Sangat } \\
\text { baik }\end{array}$ \\
\hline 2 & Structure & 1297 & 1470 & 88.23 & 4.41 & $\begin{array}{c}\text { Sangat } \\
\text { baik }\end{array}$ \\
\hline 3 & Support & 1193 & 1470 & 81.155 & 4.06 & Baik \\
\hline 4 & Identity & 1167 & 1470 & 79.39 & 3.97 & Baik \\
\hline 5 & $\begin{array}{l}\text { Conflict } \\
\text { Tolerance }\end{array}$ & 1155 & 1470 & 78.57 & 3.93 & Baik \\
\hline 6 & $\begin{array}{c}\text { Risk } \\
\text { Tolerance }\end{array}$ & 1117 & 1470 & 75.99 & 3.81 & Baik \\
\hline & Total & 7184 & 8820 & 81.45 & 4.08 & Baik \\
\hline
\end{tabular}

Sumber : Pengolahan Data

Berdasarkan Tabel 4.9 di atas, diperoleh informasi bahwa total skor aktual yang diperoleh dari seluruh pernyataanpernyataan yang membentuk variabel budaya sekolah adalah sebesar 7184 dan skor ideal sebesar 8820, sedangkan nilai total persentase yang diperoleh adalah sebesar $81,45 \%$ dan nilai mean skor sebesar 4,08 termasuk dalam kategori baik. Hal ini menunjukan bahwa budaya sekolah baik. Kategori sangat baik pada budaya sekolah jika digambarkan dengan menggunakan garis kontinum maka akan tampak sebagai berikut :

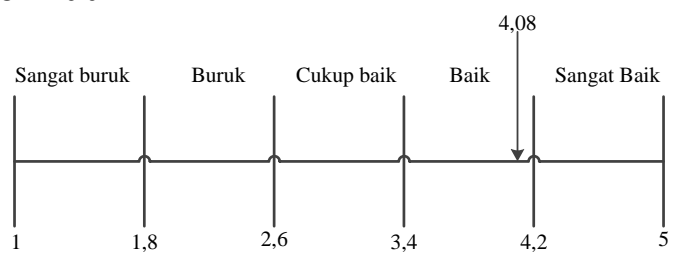

Gambar 2 Garis Kontinum Kategorisasi

Penilaian Variabel Budaya Sekolah

Untuk variabel kinerja guru, diperoleh hasil sebagai berikut.

Tabel 3 Rekapitulasi Tanggapan Responden Mengenai Kinerja Guru

\begin{tabular}{|c|c|c|c|c|c|c|}
\hline No & Dimensi & $\begin{array}{c}\text { Skor } \\
\text { actual }\end{array}$ & $\begin{array}{l}\text { Skor } \\
\text { ideal }\end{array}$ & $\%$ & $\begin{array}{c}\text { Mean } \\
\text { skor }\end{array}$ & $\begin{array}{l}\text { Kate } \\
\text { gori }\end{array}$ \\
\hline 1 & $\begin{array}{l}\text { Penyusunan } \\
\text { Rencana } \\
\text { belajar }\end{array}$ & 1193 & 1470 & 81.16 & 4.06 & Baik \\
\hline 2 & $\begin{array}{l}\text { Pelaksana- } \\
\text { an pembela- } \\
\text { jaran }\end{array}$ & 3982 & 5145 & 77.40 & 3.87 & Baik \\
\hline 3 & $\begin{array}{l}\text { Penilaian } \\
\text { prestasi } \\
\text { belajar }\end{array}$ & 1519 & 2205 & 68.89 & 3.45 & Baik \\
\hline 4 & $\begin{array}{l}\text { Pelaksana- } \\
\text { an tindak } \\
\text { lanjut hasil } \\
\text { penilaian }\end{array}$ & 2107 & 2940 & 71.67 & 3.59 & Baik \\
\hline & Total & 8801 & 11760 & 74.78 & 3.74 & Baik \\
\hline
\end{tabular}


Berdasarkan Tabel 4.20 di atas, diperoleh informasi bahwa total skor aktual yang diperoleh dari seluruh pernyataanpernyataan yang membentuk variabel kinerja guru adalah sebesar 8801 dan skor ideal sebesar 11760 , sedangkan nilai total persentase yang diperoleh adalah sebesar $74.78 \%$ dan nilai mean skor sebesar 3.74 termasuk dalam kategori baik. Hal ini menunjukan bahwa kinerja guru baik. Kategori sangat baik pada kinerja guru jika digambarkan dengan menggunakan garis kontinum maka akan tampak sebagai berikut :

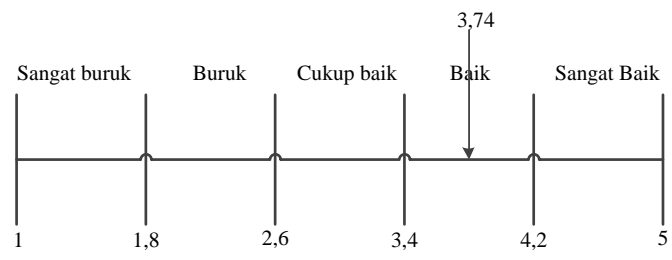

Gambar 3 Garis Kontinum Kategorisasi Penilaian Variabel Kinerja Guru

Tabel 4 Rekapitulasi Tanggapan Responden Mengenai Kualitas Hasil Belajar

\begin{tabular}{ccccccc}
\hline No & \multicolumn{1}{c}{ Dimensi } & $\begin{array}{c}\text { Skor } \\
\text { actual }\end{array}$ & $\begin{array}{c}\text { Skor } \\
\text { ideal }\end{array}$ & \% & $\begin{array}{c}\text { Mean } \\
\text { skor }\end{array}$ & $\begin{array}{c}\text { Kate } \\
\text { gori }\end{array}$ \\
\hline 1 & Aspek kognitif & 2331 & 2940 & 79.28 & 3.96 & Baik \\
2 & Aspek afektif & 1696 & 2205 & 76.92 & 3.84 & Baik \\
3 & $\begin{array}{l}\text { Aspek } \\
\text { psikomotor }\end{array}$ & 1681 & 2205 & 76.24 & 3.81 & Baik \\
\cline { 2 - 6 } & & & & & \\
\cline { 2 - 6 } & Total & 5708 & 7350 & 77.48 & 3.87 & Baik \\
\hline
\end{tabular}

Sumber : Pengolahan Data

Berdasarkan Tabel 4.24 di atas, diperoleh informasi bahwa total skor aktual yang diperoleh dari seluruh pernyataanpernyataan yang membentuk variabel kualitas hasil belajar adalah sebesar 5708 dan skor ideal sebesar 7350, sedangkan nilai total persentase yang diperoleh adalah sebesar $77.48 \%$ dan nilai mean skor sebesar 3.87 termasuk dalam kategori baik. Hal ini menunjukan bahwa kualitas hasil belajar baik. Kategori sangat baik pada kualitas hasil belajar jika digambarkan dengan menggunakan garis kontinum maka akan tampak sebagai berikut :

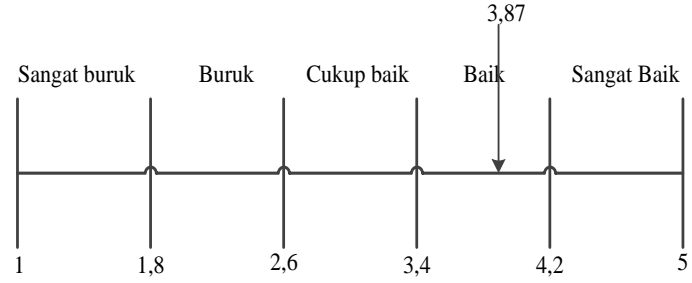

Gambar 4 Garis Kontinum Kategorisasi Penilaian Variabel Kualitas Hasil Belajar

Hasil pengolahan datas tersebut diatas menunjukan analisis nilai korelasi secara parsial maupun simultan sangat kuat serta menunjukan pengaruh determinasi secara parsial dan simultan secara kuat yang dapat digambarkan pada gambar 4.6 sebagai berikut:

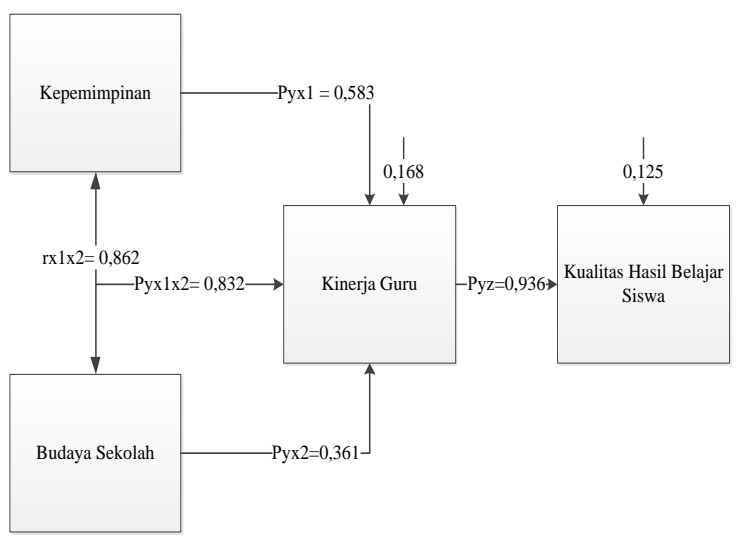

Gambar 5 Struktural Jalur Kepemimpinan dan budaya sekolah terhadap kinerja guru serta dampaknya pada kualitas hasil belajar

Dari gambar tersebut dapat dihitung berapa besar pengaruh langsung maupun tidak langsung sebagai berikut :

Untuk perhitungan pengaruh langsung adalah koefisien jalur dikuadratkan kemudian dikalikan dengan $100 \%$.

1. Pengaruh dari kepemimpinan kepala sekolah terhadap kinerja guru terdiri dari pengaruh langsung (direct effect) dan tidak langsung (indirect effect).

a. Pencarian pengaruh langsung (direct effect) kepemimpinan kepala sekolah terhadap kinerja guru adalah sebagai berikut

$D E \mathrm{x}_{1} \rightarrow \mathrm{Y}=(\rho 11 \mathrm{y})^{2} \times 100 \%$

$D E x_{1} \rightarrow Y=(0,583)^{2} \times 100 \%$

$D E x_{1}>Y=33,98 \%$

Jadi diketahui pengaruh langsung adalah sebesar 33,98 \% 
b. Pencarian pengaruh tidak langsung (indirect effect) kepemimpinan kepala sekolah terhadap kinerja guru adalah sebagai berikut

IE $\mathrm{X}_{1} \quad->\mathrm{Y}\left(\right.$ via $\left.\mathrm{X}_{2}\right)=\left(\begin{array}{llll}\rho & 11 \mathrm{X}_{1} & \mathrm{x}\end{array}\right.$ $\left.\operatorname{rX} 1 \mathrm{X} 2 \mathrm{X} \times \rho_{12} \mathrm{X}_{2}\right) \times 100 \%$

IE $x_{1}-->Y\left(\right.$ via $\left.X_{2}\right)=(0,583 \times 0,862 x$ $0,361) \times 100 \%$

IE $\mathrm{x}_{1}-->\mathrm{Y}\left(\right.$ via $\left.\mathrm{X}_{2}\right)=18,14 \%$

Jadi diketahui pengaruh tidak langsung adalah sebesar 18,14\%

c. Maka diketahui pengaruh total kepemimpinan kepala sekolah terhadap kinerja guru adalah 33,98 $\%+18,14 \%=52,12 \%$.

Jadi diketahui pengaruh total kepemimpinan kepala sekolah terhadap kinerja guru adalah sebesar $52,12 \%$.

2. Pengaruh dari budaya sekolah terhadap kinerja guru terdiri dari pengaruh langsung (direct effect) dan tidak langsung (indirect effect).

a. Pencarian pengaruh langsung (direct effect) budaya sekolah terhadap kinerja guru adalah sebagai berikut

$D E \mathrm{x}_{1}->\mathrm{Y}=(\rho 11 \mathrm{y})^{2} \times 100 \%$

$D E x_{1}->Y=(0,361)^{2} \times 100 \%$

$D E x_{1}>Y=13,03 \%$

Jadi diketahui pengaruh langsung adalah sebesar 13,03\%

b. Pencarian pengaruh tidak langsung (indirect effect) budaya sekolah terhadap kinerja guru adalah sebagai berikut

IE $\mathrm{x}_{1}-->\mathrm{Y}\left(\right.$ via $\left.\mathrm{X}_{2}\right)=\left(\rho_{11} \mathrm{X}_{1} \times \mathrm{rX}_{2} \mathrm{X}_{1} \mathrm{X} \mathrm{x}\right.$ $\left.\rho_{21} \mathrm{X}_{2}\right) \times 100 \%$

IE $x_{1}-->Y\left(\right.$ via $\left.X_{2}\right)=(0,361 \times 0,862 \times$ $0,583) \times 100 \%$

IE $\mathrm{x}_{1}-->\mathrm{Y}\left(\right.$ via $\left.\mathrm{X}_{2}\right)=18,14 \%$

Jadi diketahui pengaruh tidak langsung adalah sebesar 18,14 \%

c. Maka diketahui pengaruh total budaya sekolah terhadap kinerja guru adalah 13,03 \%+18,14 \%= $31,17 \%$.

Jadi diketahui pengaruh total budaya sekolah terhadap kinerja guru adalah sebesar 31,17 \%.

3. Secara Bersama-sama kepemimpinan kepala sekolah dan budaya sekolah mampu mempengaruhi kinerja guru sebesar 83,29\% dan sisanya sebesar $16,71 \%$ dipengaruhi oleh faktor-faktor lain yang tidak diteliti.

Pada analisis kepemimpinan kepala sekolah, budaya sekolah dan kinerja guru dapat dituliskan dalam model koefisien sistematis sebagai berikut :

$\mathrm{Y}=0,583 \mathrm{X} 1+0,361 \mathrm{X} 2+0,168 \varepsilon$

Dimana :

$\mathrm{Y}$ : Kinerja guru

$\mathrm{X}_{1}$ : Kepemimpinan kepala sekolah

$\mathrm{X}_{2}$ : Budaya sekolah

4. Pengaruh dari kinerja guru terhadap kualits hasil belajar terdiri dari pengaruh langsung (direct effect) dan tidak langsung (indirect effect) adalah $0,875 \mathrm{x}$ $100 \%=87,5 \%$ dan sisanya sebesar $12,50 \%$ dipengaruhi oleh faktor-faktor lain yang tidak diteliti.

Model ini mengandung makna bahwa Pengaruh langsung kepemimpinan kepala sekolah terhadap kinerja guru adalah sebesar 33,98 \%, pengaruh langsung dari budaya sekolah terhadap kinerja guru adalah sebesar 13,03\% . Sedangkan pengaruh tidak yaitu kepemimpinan kepala sekolah terhadap kinerja guru melalui budaya sekolah atau budaya sekolah terhadap kinerja guru melalui kepemimpinan kepala sekolah adalah sebesar $=(0,583) \times(0,862) \times(0,361) \times$ $100 \%=18,14 \%$. Maka model path dalam analisis kepemimpinan kepala sekolah, budaya sekolah terhadap kinerja guru yaitu sebesar 83,29 \%. Struktur selanjutnya adalah pengaruh kinerja guru terhadap kualitas hasil belajar adalah sebesar 87,5\%.

Analisis jalur digunakan untuk meprediksi perubahan nilai variable dependen apabila nilai variabel independen naik atau turun nilainya. Dalam penelitian ini analisis jalur digunakan karena variabel yang menjadi kajian dalam penelitian ini terdiri dari dua variabel independen yaitu kepemimpinan kepala sekolah sebagai variabel $\mathrm{X}_{1}$ dan budaya sekolah sebagai variabel $X_{2}$, satu variable intervening yaitu kinerja guru dan variable dependen yaitu kualitas hasil belajar, sehingga dapat diketahui dan dapat dibuktikan sejauh mana hubungan kepemimpinan kepala sekolah 
dan budaya sekolah terhadap kinerja guru dan kinerja guru terhadap kualitas hasil belajar.

Koefisien yang terdapat pada persamaan diatas maka dapat dijelaskan sebagai berikut :

1. Kepemimpinan kepala sekolah memiliki koefisien bertanda positif sebesar 0,583, artinya setiap peningkatan kepemimpinan kepala sekolah sebesar 1 kali diprediksi akan meningkatkan kinerja guru sebesar 0,583 kali, dengan asumsi budaya sekolah tidak berubah.

2. Modal Intelektual memiliki koefisien bertanda positif sebesar 0,361, artinya eningkatan budaya sekolah sebesar 1 kali diprediksi apkan meningkatkan kinerja guru sebesar 0,361 kali dengan asumsi kepemimpinan kepala sekolah tidak berubah.

3. Kinerja guru memiliki koefisien bertanda positif sebesar 0,875, artinya peningkatan kualitas hasil belajar siswa sebesar 1 kali diprediksi akan meningkatkan kinerja guru sebesar 0,875 kali dengan asumsi kepemimpinan kepala sekolah dan budaya sekolah tidak berubah.

\section{SIMPULAN}

Terdapat pengaruh kepemimpinan kepala sekolah terhadap kinerja guru dengan kadar kekuatan pengaruh yang positif. Mengandung arti bahwa semakin baik persepsi seorang guru mengenai kepemimpinan kepala sekolah, maka semakin baik pula kinerjanya. Terdapat pengaruh budaya sekolah terhadap kinerja guru dengan kadar kekuatan pengaruh yang positif. Mengandung arti bahwa semakin baik persepsi seorang guru mengenai budaya sekolah, maka semakin baik pula kinerjanya.

pengaruh kepemimpinan kepala sekolah dan budaya sekolah secara bersama-sama terhadap kinerja guru dengan kadar kekuatan pengaruh yang positif. Mengandung arti bahwa semakin baik persepsi seorang guru mengenai kepemimpinan kepala sekolah dan budaya sekolah, maka semakin baik pula kinerjanya. Hasil dalam penelitian ini membuktikan bahwa variabel budaya sekolah lebih berpengaruh secara positif dibandingkan variabel kepemimpinan kepala sekolah, terhadap variabel kinerja guru. Terdapat pengaruh kinerja guru terhadap mutu hasil belajar dengan kadar kekuatan pengaruh yang positif. Mengandung arti bahwa semakin baik persepsi seorang guru mengenai kinerja guru, maka semakin baik pula mutu belajar siswanya.

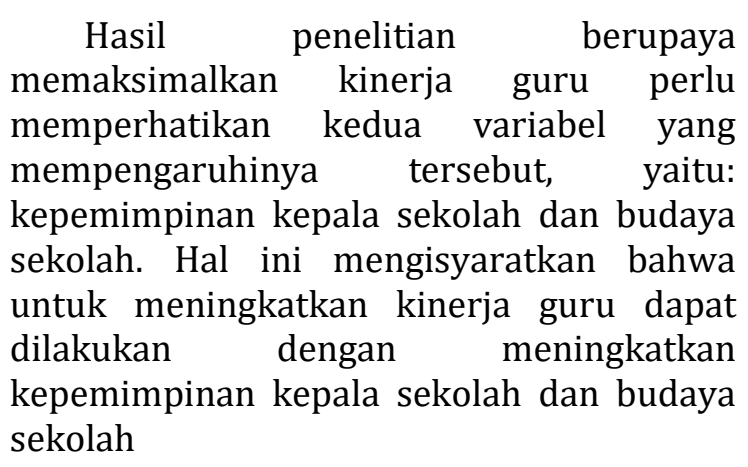

\section{DAFTAR PUSTAKA}

Agus Ruswandi, (2011). Pengaruh Supervisi Akademik oleh Pengawas Sekolah terhadap Kinerja Guru Rintisan Sekolah Menengah Atas Bertaraf Internasional di Provinsi Lampung. Jakarta : UI.

Akinola Oluwatoyin Bolanle. (2013). Principals Leadership Skills and School Effectiveness: The Case of South Western Nigeria Journal. Nigeria.

Arikunto, S. (2010). Prosedur Penelitian; Suatu Pendekatan Praktik. Edisi revisi. Jakarta : Rineka Cipta.

Bothaasah, (2010). School Effectiveness : Conceptualising Divergent Assesment Approaches, South African Journal of Education vol. 30. n.4 Pretoria.

Depdiknas. (2007). Peraturan Menteri Pendidikan Nasional Republik Indonesia Nomor 12 Tahun 2007 Tentang Standar Pengawas Sekolah/ Madrasah. Jakarta : Depdiknas.

Fahmi, Irham. (2010). Manajemen Kinerja Teori dan Aplikasi. Bandung : Alfabeta. 
Fullan, M. (2001). Leding in a Culture of Change. Jossey Bass : San Fransisco.

Hasibuan, M. (2001). Organisasi dan Motivasi. Jakarta : Bumi Aksara.

Mangkunegara, (2003). Perencanaan dan pengembangan Sumber Daya Manusia. Bandung : Refika Aditama.

Mulyasa, Enco. (2010). Menjadi Guru Profesional; Menciptakan Pembelajaran Kreatif dan Menyenangkan. Bandung : Remaja Rosdakarya.

Sedarmayanti. (2001). Sumber Daya Manusia. Jakarta : Bumi Aksara.

Semiha Sahin. (2011). The Relationship between Instructional Leadership Style and School Culture (Izmir Case). Dokuzey University.

Supardi. (2010). Kinerja Guru. Jakarya : Grafindo Persada.
Thamsanqa Thulani Bhengu and Themba Thulani Mthembu. (2014). Effective leadership, School Culture and School Effectiveness : A Case Study of Two Sister School in Umlazi Township. University of KwaZulu-Natal, South Africa.

Thoha, Miftah. (2006). Kepemimpinan dalam Manajemen. Jakarta : Grafindo Persada.

Uno, Hamzah B dan Lamatenggo, Nina. (2014). Teori Kinerja dan Pengukurannya. Jakarta : Bumi Aksara.

\section{BIOGRAFI PENULIS}

\begin{tabular}{|l|l|}
\hline Ade Prayoga, Mahasiswa Program Pascasajana Magister Ilmu Administrasi, \\
Universitas Majalengka, Provinsi Jawa Barat, Indonesia \\
Email: adeprayoga@gmail.com
\end{tabular}

